\title{
SELEÇÃO DE MARCADORES ISSR PARA Schizolobium parahyba var. amazonicum (Huber ex. Ducke) Barneby
}

\author{
Adelson Lemes da Silva Júnior ${ }^{1}$ \\ Lucimara Cruz de Souza ${ }^{2}$ \\ Aléxia Gonçalves Pereira ${ }^{3}$ \\ Kelmer Mozer Moro 4 \\ Mariana Cruz de Souza ${ }^{5}$ \\ Alessandra Abreu Rodrigues ${ }^{6}$ \\ Izabela Ferreira Ribeiro ${ }^{7}$ \\ Fábio Demolinari de Miranda ${ }^{8}$ \\ Marcos Vinicius Winckler Caldeira ${ }^{9}$
}

Resumo: O objetivo deste trabalho foi selecionar primers ISSR para serem utilizados em futuras análises de diversidade genética em população de S. amazonicum, conhecido popularmente como Paricá. Para isto, foram utilizadas folhas coletadas em 5 indivíduos da espécie em estudo, para a realização da extração e purificação do DNA genômico. Posteriormente, as amostras de DNA foram submetidas a ensaios de PCR utilizando 43 primers, seguida por eletroforese em gel de agarose, de modo a permitir a avaliação e seleção dos primers com maior qualidade de amplificação. Foram selecionados 11 primers por possuírem número considerável de locos polimórficos, além de serem nítidos e bem definidos. Os primers selecionados geraram 129 fragmentos, demonstrando que a quantidade de marcadores moleculares ISSR utilizados neste estudo são suficientes para quantificar a diversidade genética em futuros trabalhos com populações da espécie.

Palavras-chave: Paricá; Seleção de primers; Diversidade genética.

\footnotetext{
${ }^{1}$ Mestre em Genética e Melhoramento/UFES, Brasil. E-mail: adelsonlemes@yahoo.com.br.

2 Mestranda em Genética e Melhoramento/UFES, Brasil. E-mail: lucimaracruz15@hotmail.com.

${ }^{3}$ Bióloga/UFES, Brasil. E-mail: alexiagp@gmail.com.

${ }^{4}$ Ciências Biológicas/UFES, Brasil. E-mail: kelmer.moro@gmail.com.

${ }^{5}$ Agronomia/UFES, Brasil. E-mail: scruz.mariana@gmail.com.

6 Doutoranda em Genética e Melhoramento/UFES, Brasil. E-mail: abreuepires@gmail.com.

7 Mestranda em Biodiversidade Tropical/UFES, Brasil. E-mail: izabelafribeiro@gmail.com.

8 Prof. Doutor em Genética e Melhoramento/UFES, Brasil. E-mail: fademolinari@yahoo.com.br.

${ }^{9}$ Prof. Doutor em Ciências Florestais/UFES, Brasil. E-mail: mvwcaldeira@gmail.com.
} 